\title{
Aplikasi Al-barzanji Nahdlatul Wathan (NW) Berbasis Android
}

\author{
Rasyid Hardi Wirasasmita ${ }^{\text {* }}$, Muhammad Zamroni Uska², Usuluddin ${ }^{3}$, Muslihun ${ }^{4}$ \\ 1,2,4, Program Studi Pendidikan Informatika, Universitas Hamzanwadi \\ 3 Program Studi Pendidikan Bahasa Inggris, Universitas Hamzanwadi \\ *rasyidhw.pinformatika@hamzanwadi.ac.id
}

\begin{abstract}
Abstrak
Nahdhatul Wathan (NW) adalah organisasi massa Islam dari Nusa Tenggara Barat, lebih khusunya di Lombok Timur. Salah satu bentuk kecintaan dan rasa hormat terhadap organisasi NW tersebut dapat diwujudkan dengan cara membaca sholawat Al-barzanji NW. Akan tetapi buku Al-Barzanji yang digunakan sebagian besar hasil fotocopy sehingga huruf, baris dan kalimatnya kurang jelas.Tujuan penelitian ini adalah 1). menghasilkan aplikasi Al-barzanji berbasis android, 2). mengetahui kelyakan aplikasi berdasarkan ahli media dan 3). Mengetahui respon pengguna terhadap aplikasi Al-Barzanji berbasis android bagi organisasi NW. Penelitian ini menggunakan model ADDIE dengan tahapan analisis, desain, pengembangan, implementasi dan evaluasi. Tahapan penelitian yang dilakukan sampai tahap implementasi dengan ujicoba skala terbatas. Teknik pengumpulan data menggunakan angket yang ditujukan kepada ahli Media dan 20 orang sebagai Respon Pengguna. Teknik analisis data yang digunakan adalah deskriptif kuantitatif. Hasil dari penelitian ini adalah aplikasi Al-barzanji NW berbasis android. Hasil uji aplikasi oleh ahli media memperoleh nilai $96 \%$ (sangat layak) dan respon pengguna sebesar 94\% (kategori sangat tinggi). Sehingga dapat disimpulkan bahwa aplikasi ini layak digunakan untuk warga sebagai salah satu media yang dapat digunakan dalam membaca sholawat al-barzanji.
\end{abstract}

Kata kunci: Al-barzanji, Android, Nahdhatul Wathan (NW)

\begin{abstract}
Nahdhatul Wathan (NW) is an Islamic mass organization from West Nusa Tenggara, more specifically in East Lombok. One form of love and respect for the NW organization can be realized by reading the sholawat Albarzanji NW. However, Al-Barzanji books are used mostly by photocopy so that the letters, lines and sentences are less clear. The purpose of this study is 1). generated android-based Al-Barzanji application, 2). know the application based on media experts and 3). Know the user's response to the Android-based Al-Barzanji application for NW organizations. This research uses the ADDIE model with stages of analysis, design, development, implementation and evaluation. The research stage is carried out until the implementation stage with limited-scale trials. Data collection techniques use questionnaires addressed to Media experts and 20 people in User Response. The data analysis technique used is quantitative descriptive. The result of this study is the Android-based Al-Barzanji NW app. Application test results by media experts received a score of $96 \%$ (very decent) and user response by $94 \%$ (very high category). So, it can be concluded that this application is worth implemented for citizens as one of the media that can be used in reading sholawat al-barzanji.
\end{abstract}

Keywords: Al-barzanji, Android, Nahdhatul Wathan (NW) 


\section{PENDAHULUAN}

Penghormatan dan kecintaan ummat Islam kepada Nabi

Muhammad

Sallahu'alaihiawasallam (S.A.W) begitu kuat dan mendalam sepanjang hayatnya, bahkan setelah wafatnya. Bentuk cinta dan hormat itu diwujudkan dengan cara bersholawat dan mengenang cerita hidup dari sejak lahir hingga beliau wafat. Salah satu cara mengenang Nabi Muhammad S.A.W yang dilakukan oleh kebanyakan orang atau organisasi islam khususnya organisasi Nahdlatul Wathan yaitu dengan membaca shalawat maulid Al-barzanji Nahdhatul Wathan. Shalawat Maulid Al-barzanji merupakan kumpulan nazhom-nazhom tentang sholawat kepada Nabi Muhammad S.A.W. Tertulis dalam buku Al-barzanji kemudian menjadi amalan ummat islam khususnya warga Nahdlatul Wathan di setiap malam Jum'at menggunakan buku Al-barzanji Nahdlatul Wathan.

Penggunaan media seperti buku adalah hal biasa dalam proses membaca, tetapi pemanfaatan dan pemberdayaan teknologi untuk menunjang pembelajaran merupakan suatu keniscayaan, bukan hanya untuk meningkatkan penguasaan dan kualitas pembaca, namun yang lebih penting adalah memberikan kemudahan dalam proses pembacaan.

Berdasarkan hasil observasi dan wawancara yang dilakukan dikalangan masyarakat di Desa
Aik Bual ketika membaca Al-barzanji masalah yang ditemukan adalah dalam proses pembacaanya masih banyak warga khususnya dikalangan anak-anak dan remaja (pemula) yang tidak membawa buku Al-barzanji, bahkan tidak sedikit dari mereka yang tidak memiliki buku Albarzanji, adapun yang biasa memiliki buku Albarzanji biasanya hanya dari kalangan orang tua atau guru, buku yang tersediapun tidak dibentuk dengan begitu menarik dan tidak terlalu jelas dikarnakan tulisan atau bacaan yang disediakan banyak menggunakan hasil scan atau potocopy, sehingga tidak sedikit juga dari banyaknya buku Al-barzanji yang beredar terdapat beberapa huruf dan kalimat yang kurang jelas sehingga menyebakan kurang efektif dalam membaca, terutama untuk para pemula. Berdasarkan hal inilah yang menjadi landasan utama dalam penelitian yang kami lakukan untuk membuat media atau aplikasi Al-barzanji Nahdlatul Wathan Berbasis Android.

Terkait dengan aplikasi berbasis android, sejumlah peneliti telah mengembangkan aplikasi tersebut pada bidang yang berbeda-beda. Nurhidayati \& Nur telah mengembangkan aplikasi sistem informasi persebaran indekos berbasis android yang berfungsi untuk membantu pengguna mencari kos yang strategis [1]. Peneliti lain juga telah mengembangkan media pembelajaran berbasis android pada pembelajaran biologi, sehingga dapat 
memudahkan siswa atau pengguna dalam mehami materi yang telah di berikan oleh guru [2]-[4]. Sementara itu Bahtiar, Wasil \& Harianto membuat aplikasi berbasis android atau smartphone sebagai media pembelajaran interaktif untuk pelestarian peninggalan pendiri Nahdlatul Wathan dengan hasil mendigitalisasikan karya-karya TGKH. Muhammad Zainuddin Abdul Madjid (Hamzanwadi) kedalam bentuk Website dan aplikasi berbasis android [5] .

Selanjutnya, Vince et al., telah mengembangkan aplikasi berbasis android untuk mempermudah pembuatan web menggunakan prangkat mobile, sehingga dapat menghemat waktu, dan dapat menghemat daya dalam mengembangkan aplikasi tersebut [6]. Peneliti lain juga telah membuat atau mengembangkan aplikasi berbasis android Bernama NEU-CEIT. Dimana aplikasi ini berfungsi untuk meningkatkan motivasi dan dapat mendukung proses pembelajaran pemrograman dasar ditingkat akademik (Universitas) [7].

Berdasarkan hal tersebut di atas, mengenai beberapa aplikasi mobile (berbasis andoid) yang telah dikembangkan oleh beberapa peneliti diberbagai bidang, maka penelitian ini penting untuk dilakukan, karena sebagian besar pengguna menggunakan smartphone berbasis android dan banyak aplikasi yang dimanfaatkan untuk mempermudah pekerjaan seseorang pada bidang masing-masing. Oleh karena itu, untuk mempermudah pengguna dalam menggunakan (membaca) al-barzanji, pada penelitian ini berfokus atau bertujuan untuk mengembangkan aplikasi Al-Barzanji NW berbasis android, menguji kelayakan, serta mengetahui respon pengguna. Dengan adanya aplikasi ini dapat dijadikan sebagai media yang dapat mempermudah proses pembacaan sholawat nabi oleh warga NWI. Dimana aplikasi ini terdiri berbabai doa seperti surat yasin, al-barzaji, dan doa penutup.

\section{Tinjauan Pustaka}

\subsection{Penelitian Terkait}

Penelitian sebelumnya yang telah dilakukan oleh [5] mengenai digitalisasi karya TGKH. Muhammad Zainuddin Abdul Madjid yang dijadikan sebagai media pembelajaran berbasis mobile (android). Dimana hasil penelitian mereka adalah menghasilkan sebuah aplikasi yang dijadikan sebagai media pembelajaran untuk pelestarian peninggalan pendiri Nahdlatul Wathan. Oleh karena itu, dengan adanya media tersebut adalah salah satu solusi untuk muridmurid beliau yang notabennya tidak memiliki kitab tersebut dan terhalang dengan jarak dan waktu. Pengerjaan dimulai dengan pengetikan isi kitab yang dilanjutkan dengan implementasi aplikasi, dan pada akhirnya aplikasi bisa dimanfaatkan lebih lanjut. 
DOI : 10.29408/jit.v5i1.4668 Link : https://dx.doi.org/10.29408//jit.v5i1.4668

Selanjutnya penelitian yang dilakukan oleh Aini et al., telah mengembangkan aplikasi atau pembelajaran berbasis android pada pembelajaran jaringan dasar [8]. Dengan adanya media ini dapat membantu siswa di jenjang Sekolah Menengah Kejuruan (SMK) mengenai jaringan dasar, dapat digunakan dimana saja dan kapanpun yang akses melalui smartphone yang memiliki sistem operasi android. Selain itu penelitian lain juga yang dilakukan oleh Amna et al., telah membuat atau mengembangkan aplikasi berbasis android yang dijadikan sebagai media pembelajaran pada perkuliahan sistem operasi [9]. Dimana hasil penelitian mereka menunjukkan bahwa media tersebut layak digunakan, serta memiliki respon yang positif dari pengguna. Oleh karena itu, dengan adanya media ini, pengguna merasa terbantukan dalam memahami materi sistem operasi, dimana media tersebut terdapat materi yang disajikan dalam bentuk gambar, serta adanya video tutorial mengenai bagaimana cara instalasi sistem operasi, terutama pada sistem operasi windows.

\subsection{Landasan Teori}

Android merupakan sistem operasi yang dikembangkan untuk perangkat mobile berbasis Linux. Pada awalnya sistem operasi ini dikembangkan oleh Android Inc. yang kemudian dibeli oleh Google pada tahun 2005 (Maiyana, 2018). Anwar, Nugroho \& Lestariningsih juga mengatakan android merupakan sistem operasi mobile. Android tidak membedakan antara aplikasi inti dengan aplikasi pihak ketiga. Application Programming Interface (API) yang disediakan menawarkan akses ke hardware, maupun data-data ponsel sekalipun atau data sistem sendiri, bahkan pengguna dapat menghapus aplikasi inti dan menggantikannya dengan aplikasi pihak ketiga [11].

Prabowo \& Heriyanto menyatakan bahwa buku elektronik juga dikenal dengan istilah buku digital adalah versi elektronik dari buku [12]. Ebook ini juga dapat memuat berbagai informasi baik tulisan, gambar, grafik atau lainnya [13]. Selain itu, Ebook merupakan buku elektronik sebagai pengganti buku kertas yang dapat dibuka dalam perangkat elektronik (smartphone, laptop atau PC) [14]. Eskawati juga menerangkan bawa ebook atau buku digital merupakan buku dalam format elektronik berisikan informasi yang dapat berwujud teks atau gambar [15]. Saat ini, E-book yang beredar di pasaran telah mengalami berbagai perkembangan. E-book diminati karena ukurannya yang kecil, tidak mudah lapuk, dan mudah di bawa. Keunggulan e-book yang lain adalah dapat menampilkan ilustrasi multimedia dan lainnya. Sehingga didapatan kesimpulan bahwa buku digital adalah sebuah buku teks yang dikonversi kedalam bentuk digital (E-book) yang dapat menampilkan ilustrasi multimedia 
DOI : 10.29408/jit.v5i1.4668 Link : https://dx.doi.org/10.29408//jit.v5i1.4668

dan lainnya bisa ditampilkan didalam komputer atau smartphone.

Nisa \& Hasan menyatakan kitab Al-barzanji adalah sebutan lain dari kitab lqd Al-Jawahir (kalung permata), sebuah karya tulis seni yang memuat kehidupan Nabi Muhammad SAW [16]. Ashari juga mengungkapkan bahwa Al-Barzanji merupakan sebuah karya sastra Arab berbentuk prosa yang berisi tentang sejarah kehidupan Rasulullah saw yang dilukiskan dengan kata-kata indah, Karya sastra ini dibaca dalam berbagai upacara keagaman di dunia Islam, sebagai bagian yang menonjol dalam kehidupan agama tradisional dengan membacanya diharapkan dapat meningkatkan keimanan dan kecintaan terhadap Nabi Muhammad SAW [17].

\section{Metode Penelitian}

Pada penelitian yang kami lakukan menggunakan pendekatan penelitian dan pengembangan atau Research and Development (R\&D) dengan model ADDIE. Model ADDIE merupakan langkah pengembangan yang terdiri dari Analysis (Analisis), Design (Desain), Development (Pengembangan), Implementation (Implementasi), dan Evaluation (Evaluasi). Model ADDIE dikembangkan untuk merancang sistem pembelajaran [18]. Model yang digunakan (ADDIE) dapat dilihat apda gambar 1.

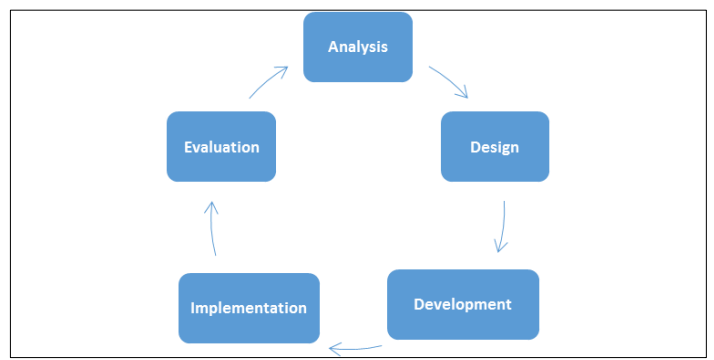

Gambar 1. Model ADDIE (Alur Penelitian)

Berdasarkan gambar 1, alur penelitian yang kami lakukan adalah yang pertama tahap analisis. Tahap analisis dilakukan menentukan masalah, dengan cara wawancara atau observasi, mengumpulkan data, mengidentifikasi masalah masalah dan menentukan solusi yang memungkinkan untuk melengkapi media atau aplikasi al-barzanji yang kami buat. Tahap yang kedua adalah tahap desain. Dimana tahap ini dilakukan. merencanakan strategi pada intruksi pengembangan. tahap desain atau perancangan produk seperti tahapan pembuatan desain media (Al-Barzanji).

Tahap selanjutanya adalah pengembangan (development). Pada tahap ini produk awal buku digital shalawat Al-barzanji NW berbasis android dengan menerapkan kerangka produk, dilakukan pengumpulan bahan, pengumpulan materi. Rancangan kerangka produk ini diterapkan menjadi produk awal buku digital shalawat Albarzanji NW menggunakan software Android studio. Selanjutnya, Validasi dilakukan oleh ahli media yang hasilnya merupakan saran, komentar, dan masukan yang dapat digunakan sebagai dasar untuk melakukan analisis dan 
DOI : 10.29408/jit.v5i1.4668 Link : https://dx.doi.org/10.29408//jit.v5i1.4668

revisi terhadap produk yang dikembangkan dan

sebagai dasar untuk uji coba pada produk pada pengguna.

Selanjutya yang terkahir adalah tahap implementasi (implementation), karena pada penelitian ini kami hanya pada tahap implementasi, tidak sampai pada tahap evaluasi.

Pada tahap ini dilakukan diimplementasikan rancangan dan metode yang telah dikembangkan pada situasi yang nyata di Desa Aik Bual. Selama implementasi, rancangan produk yang telah dikembangkan diterapkan pada kondisi yang sebenarnya. Selanjutnya dilakukan evaluasi awal pada tahap implementasi untuk memberi umpan balik. Produk berupa buku digital yang sudah dinyatakan layak oleh ahli dan diuji coba kepada pengguna di Desa Aik bual.

Subjek yang terlibat dalam penelitian ini adalah 2 orang ahli media dan 20 orang pengguna sebagai responden. Teknik pengumpulan data yang digunakan adalah berupa angket dengan sekala likert. Sementara itu teknik analisis data yang digunakan adalah deskriptif kuantitatif. Data yang diperoleh dari ahli media kemudian dijumlahkan dan di bandingkan dengan mengugnakan persamaan 1. Selanjutnya, untuk mencari penilaian respon pengguna digunakan rumus persentase nilai respon siswa menggunakan persamaan 2
Presentasi kelayakan (\%) =

$\frac{\text { skor yang di dapat }}{\text { skor yang di harapkan }} 100 \%$

Keterangan:

Skor yang didapat $=$ skor keseluruhan jawaban responden

Skor yang diharapkan $=$ skor maksimal perbutir $\mathrm{x}$ jumlah pertanyaan $\mathrm{x}$ jumlah responden

Nilai respon pengguna $(\%)=$

$\frac{\text { Jumlah skor responden }}{\text { Skor ideal }} \times 100 \%$

Keterangan:

Skor ideal $=$ Skor maksimal $\mathrm{x}$ jumlah responden $\mathrm{NRP} \%=$ Nilai Respon Pengguna

\section{Hasil dan Pembahasan}

Hasil analisis yang telah kami lakukan adalah Media dibuat menggunakan beberapa perogram pendkung yaitu Android Studio sebagai sofware uutama untuk memerogram aplikasi dan Adobe Potoshop sebagai aplikasi pendukung untuk mendesain gambar pada aplikasi. Selanjutnya perangkat keras yang dibutuhkan untuk menjalankan atau mengoperasikan media adalah smartphone berbasis Android dengan versi Android minimal adalah Android Kit Kat 4.4.

Hasil pengembangan produk yang telah kami lakukan adalah sebuah media atau aplikasi AlBarzanji berbasis android beresktensi .apk. aplikasi ini terdiri dari menu utama, menu full AlBarzanji, menu teks dan arti, menu lirik lagu NW, serta menu profil. Gambar 1 adalah interface menu utama. Dimana menu ini terdapat menu- 
menu yang tersedia yakni terdapat gambar bergerak sendiri di atas tombol, tombol Full Albarzanji NW, Teks dengan Arti Al-barzanji NW, Lirik Mars NW, dan Tentang Aplikasi.

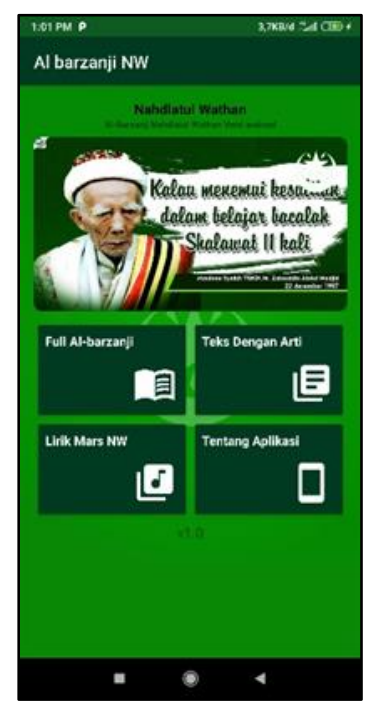

Gambar 1. Menu Utama

Selanjutnya, halaman menu full Al-Barzanji yang terlihat pada gambar 2. Pada menu ini menampilkan bacaan Full Al-barzanji yang dimulai dara bacaan Qiro'autul Fatihah, Sgakawat Nahdathain, Surat Yaasin, Al-barzanji, Tola'al Badru'alaina, Asroqal Badrul 'alaina, ilahitammiminna'ma, Sholatul Badriah, dan Do'a. Menu selanjutnya adalah menu teks dan arti. Pada halaman atau menu ini menampilkan bacaan Full Al-barzanji NW dari awal hingga ahir yang dilengkapi dengan arti disetiap bacaannya yang dapat dilihat pada gambar 3 .

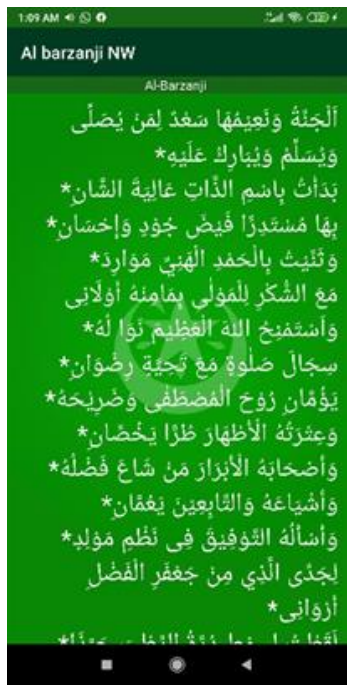

Gambar 2. Menu Full Al-barzanji

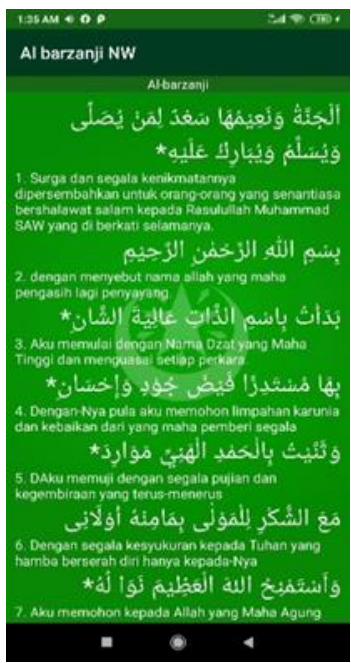

Gambar 3. MenuTeks dengan Arti

Menu lirik lagu NW menampilkan bacaan bebarapa lirik Mars NW lengkap dengan arti dan diatur dengan sesuai. Berikut ini tampilan menu Lirik Mars NW yang terdiri dari liri Imam Kita Imam Syafi'i, Mari Kita Bernyanyi Bersama, Indonesia, Selamat Datang, Bersinar-Sinar, dan Wahai Pancor, yang ditampilkan pada gambar 4. Sementara itu, menu yang terkahir adalah profil. Dimana menu ini menampilkan keterangan 
DOI : 10.29408/jit.v5i1.4668 Link : https://dx.doi.org/10.29408//jit.v5i1.4668

Aplikasi, penjelasan shalawat Al-barzanji secara umum, petunjuk pengguna dan profile pengembang yang Nampak pada gambar 5 .

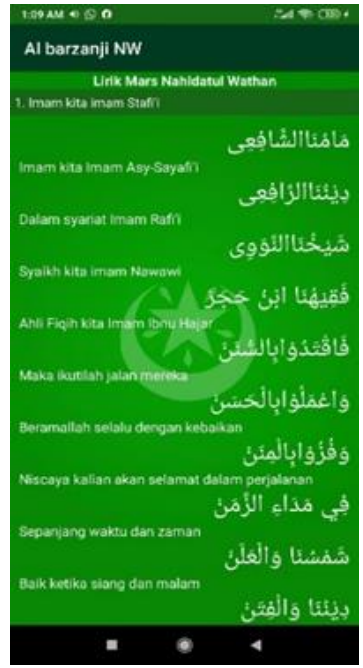

Gambar 4. Menu Lirik Mars NW

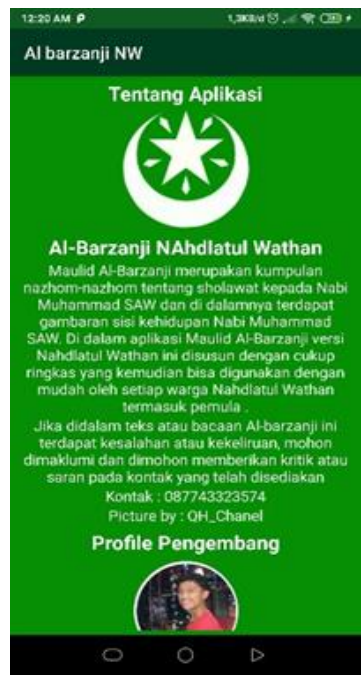

Gambar 5. MenuTentang Aplikasi

Hasil pengujian (kelayakan) pada aplikasi oleh ahli media dapat dilihat pada tabel 1 dan gambar 6. Berdasarkan hasil tersebut menunjukkan bahwa pada aspek kemanfaatan isi mendapatkan persentase $100 \%$ dengan kategori sangat layak. Sementara itu, pada aspek tampilan memperoleh nilai persentase sebesar
92\% dengan kategori sangat layak. Oleh karena diperoleh hasil rerata persentase sebesar 96\% dengan kateori sangat layak. Berdasarkan hasil tersebut mengindisikan bahwa media atau aplikasi yang telah dikembangkan mudah digunakan, tampilan teks dan gambar sudah sesuai, tidak menggunakan jenis huruf yang banyak, menggunakan latar belakang (backround) yang sesuai dengan media ini, serta penempatan teks al qura'an dan arti ditempatkan dengan akurat.

Tabel 1. Hasil Persentase Kelayakan Ahli Media

\begin{tabular}{|l|l|c|c|}
\hline No & \multicolumn{1}{|c|}{ Aspek } & $\begin{array}{c}\text { Persent } \\
\text { ase }\end{array}$ & Kategori \\
\hline 1 & Kemanfaatan & $100 \%$ & Sangat layak \\
\hline 2 & Tampilan & $92 \%$ & Sangat layak \\
\hline \multicolumn{2}{|c|}{ Rerata persentase } & $96 \%$ & Sangat layak \\
\hline
\end{tabular}

Hasil pengujian ini relevan dengan hasil temuan [9][8][19][20], dimana hasil temuan mereka mengungkapkan bahwa produk yang telah mereka kembangkan dapat membantu pengguna dalam proses pembelajaran, mudah digunakan, dan fleksibel, sehingga dapat digunakan dimanapun dan kapan saja.

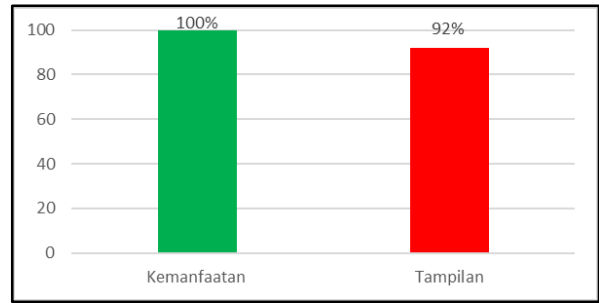

Gambar 6. Hasil Uji Kelayakan oleh Ahli Media Selanjutnya, hasil respon pengguna terhadap aplikasi Al-Barzanji yang disajikan pada tabel 2 dan gambar 7. Berdasarkan hasil tersebut 
menunjukkan bahwa pada aspek kebermanfaatan (usefullnes) memperoleh nilai sebesar $94 \%$ dengan kategori sangat tinggi, pada aspek easy of use sebesar $95 \%$ dengan kategori sangat tinggi, aspek easy of learning memperoleh nilai 95\% dengan kategori sangat tingg, dan pada aspek satisfaction memperoleh nilai sebesar $94 \%$ dengan kategori sangat tinggi juga. Hasil rerata persentase pada respon pengguna memperoleh nilai sebesar $94 \%$ dengan kategori sangat tinggi.

Tabel 2. Hasil Persentase Repon Pengguna

\begin{tabular}{|c|c|c|c|c|c|}
\hline Responde & \multicolumn{4}{|c|}{ Aspek Usability } & \multirow{2}{*}{ Total } \\
\hline 20 orang & $\begin{array}{l}\text { Usefu } \\
\text { Ilnes }\end{array}$ & $\begin{array}{l}\text { Ease } \\
\text { of Use }\end{array}$ & $\begin{array}{l}\text { Eas } \\
\text { y of } \\
\text { Lear } \\
\text { ning }\end{array}$ & $\begin{array}{c}\text { Sati } \\
\text { sfact } \\
\text { ion }\end{array}$ & \\
\hline Jumlah & 564 & 858 & 284 & 566 & \multirow{2}{*}{2.272} \\
\hline Persen & $94 \%$ & $95 \%$ & $95 \%$ & $94 \%$ & \\
\hline $\begin{array}{c}\text { Jumlah } \\
\text { skor }\end{array}$ & \multicolumn{5}{|c|}{2400} \\
\hline $\begin{array}{c}\text { Persentas } \\
\mathrm{e}\end{array}$ & \multicolumn{5}{|c|}{$94 \%$} \\
\hline
\end{tabular}

Berdasarkan hasil tersebut menunjukkan bahwa aplikasi Al-Barzanji ini dalam penerapannya, pengguna merasa mudah dalam mengoperasikan aplikasi Al-Barzanji ini, bermanfaat bagi pengguna, mudah dipelajari, serta penggua merasa puas dengan adanya aplikasi Al-Barzanji berbasis android ini. Hasil temuan kami ini relevan dengan hasil temuan yang dilakukan oleh [21][22][23][24]. Berdasarkan hasil temuan mereka bahwa aplikasi yang telah diterapkan dapat memberikan kepuasan kepada pengguna, mudah digunakan serta mudah dipelajari. Sehingga dengan adanya aplikasi tersebut dapat menghemat waktu, efisien, dan efektif dalam melakukan aktifitas mereka sehari-hari

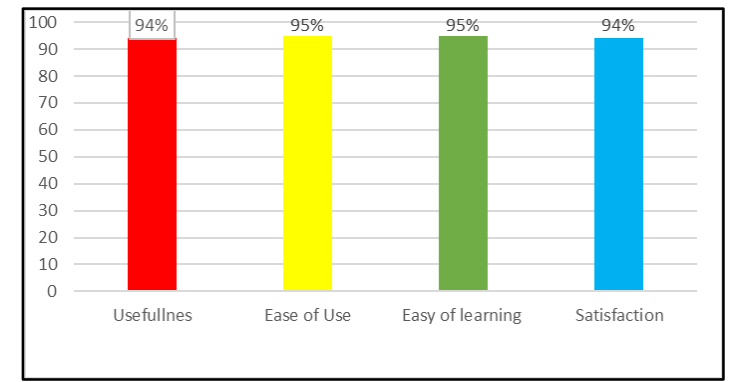

Gambar 7. Hasil Persentase Respon Pengguna

\section{Kesimpulan}

Berdasarkan hasil temuan yang telah kami maka disimpulkan bahwa produk yang kami ilkan adalah aplikasi Al-Barzanji berbasis android. Dimana aplikasi ini memiliki dapat membantu pengguna dalam membaca sholawat nabi dengan mudah dan bacaan atau teks yang ada pada aplikasi tersebut sudah jelas dan aplikasi ini juga mudah untuk digunakan. Selain itu, aplikasi ini sudah layak digunakan berdasarkan hasil uji oleh ahli media dengan kategori sangat layak, dan berdasarkan hasil respon pengguna bahwa termasuk dalam kategori sangat tinggi. Oleh karena itu aplikasi Al-Barzanji ini sangat bermaanfaat bagi para pembaca Al-Barjanji dan para pengguna juga merasa puas dengan adanya aplikasi ini khusunya di desa aik bual. Keterbatasan penelitian ini adalah subjek yang 
digunakan masih terbatas, hanya di lingkungan desa Aikbual, selain itu tahapan penelitian ini hanya dibatasi pada tahap implementasi, belum dilakukan pada tahap evaluasi yakni pada ujicoba dalam skala yang lebih besar.

\section{Daftar Pustaka}

[1] Nurhidayati and A. M. Nur, "Pemanfaatan Aplikasi Android Dalam Rancang Bangun Sistem Informasi Persebaran Indekos di Wilayah Pancor Kabupaten Lombok Timur," Infotek J. Inform. dan Teknol., vol. 4, no. 1, pp. 51-62, 2021, [Online]. Available: https://ejournal.hamzanwadi.ac.id/index.php/infote k/article/view/2989/pdf_49.

[2] N. B. Haka, "Pengembangan Komik Manga Biologi Berbasis Android untuk Peserta Didik Kelas XI Ditingkat SMA/MA," J. Biol. Educ., vol. 1, no. 1, pp. 17-32, 2020.

[3] S. Muyaroah and M. Fajartia, "Pengembangan Media Pembelajaran Berbasis Android dengan menggunakan Aplikasi Adobe Flash CS 6 pada Mata Pelajaran Biologi," Innov. J. Curric. Educ. Technol., vol. 6, no. 2, pp. 22-26, 2017.

[4] U. A. Labib and B. Yolida, "Pengembangan aplikasi berbasis android yang terintegrasi dengan website sebagai media pembelajaran biologi," $\mathrm{J}$. Bioterdidik Wahana Ekspresi IIm., vol. 7, no. 5, pp. 33-42, 2019.

[5] H. Bahtiar, M. Wasil, and B. Harianto, "Digitalisasi Karya TGKH. Muhammad Zainuddin Abdul Madjid berbasis mobile sebagai media pembelajaran interaktif untuk pelestarian peninggalan pendiri Nahdlatul Wathan," Infotek J. Inform. dan Teknol., vol. 2, no. 1, pp. 1-7, 2019.

[6] T. Vince, P. Lukáč, D. Schweiner, I. Tomčíková, and D. Mamchur, "Android application supporting developed web applications testing," in nternational Conference on Modern Electrical and Energy Systems (MEES), 2017, pp. 392395.

[7] S. Kocakoyun and H. Bicen, "Development and Evaluation of Educational Android Application.," Cypriot J. Educ. Sci., vol. 12, no. 2, pp. 58-68, 2017.

[8] N. Aini, R. H. Wirasasmita, and M. Z. Uska, "Pengembangan Mobile Learning Berbasis Android Pada Mata Pelajaran Jaringan Dasar," Edumatic J. Pendidik. Inform., vol. 2, no. 1, pp. 34-41, 2018.

[9] M. Amna, R. H. Wirasasmita, and A. Fathoni, "Pengembangan Media Pembelajaran Berbasis Android Pada Mata Kuliah Sistem Operasi di Universitas Hamzanwadi," EDUMATIC J. Pendidik. Inform., vol. 2, no. 1, pp. 1-7, 2018, doi: 10.29408/edumatic.v2i1.816.

[10] E. Maiyana, "Pemanfaatan Android Dalam Perancangan Aplikasi Kumpulan Doa," J. Sains dan Inform. Res. Sci. Inform., vol. 4, no. 1, pp. 54-65, 2018.

[11] S. N. Anwar, I. Nugroho, and E. Lestariningsih, "Perancangan Dan Implementasi Aplikasi Mobile Semarang," Din. Inform., vol. 5, no. 2, pp. 135-145, 2013.

[12] A. Prabowo and $H$. Heriyanto, "Analisis pemanfaatan buku elektronik (e-book) oleh pemustaka di perpustakaan SMA Negeri 1 Semarang," J. Ilmu Perpust., vol. 2, no. 2, pp. 152-161, 2013.

[13] I. Almas and I. Krismayani, "Kaji Tindak Penggunaan Meme Dalam Kegiatan Promosi Koleksi Ebook Di Perpustakaan Sma Negeri 3 Semarang," J. IImu Perpust., vol. 6, no. 3, pp. 441-450, 2019.

[14] G. Susanto and H. L. Purwanto, "Information retrieval menggunakan latent semantic indexing pada ebook," SMATIKA J., vol. 8, no. 02, pp. 74-79, 2018.

[15] S. Y. Eskawati, "Pengembangan E-Book Interaktif Pada Materi Sifat Koligatif 
Sebagai Sumber Belajar Siswa Kelas XII IPA," UNESA J. Chem. Educ., vol. 1, no. 2, pp. 46-53, 2012.

[16] R. A. Nisa and S. Hasan, "Nilai-nilai Pendidikan Akhlak dalam Kitab al Barzanji Karya Syaikh Ja'far al Barzanji dan Implementasinya Dalam Pendidikan," Al-I'tibar J. Pendidik. Islam, vol. 6, no. 1, pp. 50-63, 2019.

[17] H. Ashari, "Tradisi 'Berzanjen' Masyarakat Banyuwangi Kajian Resepsi Sastra terhadap Teks Al-Barzanji," Momentum, vol. 7, no. 1, pp. 129-147, 2018.

[18] R. Gusmida and N. Islami, "The development of learning media for the kinetic theory of gases using the ADDIE model with augmented reality," J. Educ. Sci., vol. 1, no. 1, pp. 1-10, 2017.

[19] M. K. Hakky, R. H. Wirasasmita, and M. Z. Uska, "Pengembangan media pembelajaran berbasis android untuk siswa kelas $x$ pada mata pelajaran sistem operasi," Edumatic J. Pendidik. Inform., vol. 2, no. 1, pp. 24-33, 2018.

[20] A. Sudianto and L. M. Samsu, "Penerapan Media Pembelajaran Interaktif Pelajaran Bahasa Indonesia Berbasis Android Untuk Kelas Vii Madrasah Tsanawiyah Nahdlatul Wathan
Ketangga Sebagai Upaya Untuk Peningkatkan Minat Belajar Siswa," Infotek J. Inform. dan Teknol., vol. 2, no. 2, pp. 53-60, 2019.

[21] I. G. L. P. Udiyana and I. G. Riana, "The Differences Patient Satisfaction Indices Using Android application and Questionnaire Method in The Puskesmas," J. Multidiscip. Acad., vol. 5, no. 3, pp. 230-233, 2021.

[22] Y.-C. Wang et al., "Patient satisfaction with dermatology teleconsultation by using MedX," Comput. Methods Programs Biomed., vol. 167, pp. 37-42, 2018.

[23] A. Sudianto and N. Hidayati, "Penerapan Sistem Informasi Tracer Study untuk Mengetahui Tingkat Kontribusi Perguruan Tinggi dengan Kompetensi Lulusan (Studi Kasus Fakultas Teknik Universitas Hamzanwadi)," Infotek J. Inform. dan Teknol., vol. 2, no. 1, pp. 43-52, 2019.

[24] M. Z. Uska and R. H. Wirasasmita, "Analisis Teknologi Smartphone dalam Mendukung Kegiatan Akademis di Universitas Hamzanwadi Menggunakan Technology Acceptance Model," Edumatic J. Pendidik. Inform., vol. 2, no. 2, pp. 51-60, 2018. 